\title{
The Effect on Foreign Direct Investment of Membership in the European Union
}

\author{
RANDOLPH LUCA BRUNO, 1 (D) NAURO FERREIRA CAMPOS ${ }^{2}$ (D) and SAUL ESTRIN ${ }^{3}$ (iD \\ ${ }^{1}$ School of Slavonic and East European Studies, University College London, London ${ }^{2}$ University College London, London ${ }^{3}$ London \\ School of Economics and Political Science
}

\begin{abstract}
This article explores the impact of EU membership on foreign direct investment (FDI). It analyses empirically how the effects of such deep integration differ from other forms and investigates what drives these effects. Using a structural gravity framework on annual bilateral FDI data for almost every country in the world from 1985 to 2018, we find EU membership leads to about 60 per cent higher FDI investment into the host economy from outside the EU, and around 50 per cent higher intra-EU FDI. Moreover, we find that the effect of EU membership on FDI is larger than from membership of the North American Free Trade Agreement, the European Free Trade Association and the Southern Common Market, and that the single market is the cornerstone of this differential impact.
\end{abstract}

Keywords: deep economic integration; foreign direct investment; European Union; structural gravity model; single market

\section{Introduction}

How much additional foreign direct investment (FDI) does a country receive because it chooses to engage in deep vis-à-vis shallow forms of integration? This is a crucial question within the European policy debate, for which, surprisingly, one still finds very few answers. The main textbooks on the economics of European integration (Baldwin and Wyplosz, 2006; De Grauwe, 2018; El-Agraa, 2011) place limited emphasis on the impact on inward FDI. Discussions about economic integration instead focus on the trade and competition effects of membership in the EU (Mayes, 1978; Anderson and van Wincoop, 2003, 2004), though the potential impact on FDI has also been recognized (Blomstrom and Kokko, 2003; Egger and Pfaffermayr, 2004).

Inward FDI plays an important role in the economic development of host economies because, as a form of capital accumulation, FDI can generate growth while, if it is sourced from technologically more advanced locations, it can lead to enhanced productivity, both horizontally within industries (Haskel et al., 2007) and vertically up and down supply

\footnotetext{
* We thank Fabrizio Coricelli, Nicholas Crafts, Swati Dhingra, Peter Egger, Jan Fidrmuc, Michele Ruta, John Springford, Richard Whitman (the editor of JCMS), four anonymous referees and seminar participants at the London School of Economics, University College London, Birkbeck College, Brunel University, University of Clermont-Ferrand, Kyoto University, Henley Business School, HM Treasury, Department for International Development, National Institute of Economic and Social Research, DIW Deutsches Institut für Wirtschaftsforschung (German Institute for Economic Research), European Central Bank, World Bank, Academy of International Business and the Regional Studies Association meetings for valuable comments on previous versions of this article. We would like also to extend a very special thanks to John Van Reenen for inviting us to write an article on the foreign direct investment effects of Brexit in the context of the work carried out at the London School of Economics Centre for Economic Performance. Dustin Voss and Yuan $\mathrm{Hu}$ provided superb research assistance. We are responsible for any errors.
} 
chains (Javorcik, 2004). Indeed, scholars have argued that the entry of foreign firms into a host economy can stimulate technological innovation (Alfaro et al., 2004), put pressure on domestic competitors (Mastromarco and Simar, 2015) and diffuse frontier management practices (Bloom et al., 2012). FDI may also exhibit patterns of complementarity not only with respect to trade, but also with other elements of financial globalization (Greenaway and Kneller, 2007; Lane and Milesi-Ferretti, 2008).

It is usually argued that EU membership increases FDI inflows, for example as a consequence of higher customs duties on trade from outside the Union, shifting the balance of advantage for external firms away from exporting and in favour of FDI (Baldwin and Wyplosz, 2006). Such impacts have been widely documented, for instance, by the increase in inward FDI following announcements about future EU membership on FDI in transition economies in the 1990s (Bevan and Estrin, 2004; Bruno and Cipollina, 2018; Crespo and Fontoura, 2007; Medve-Bálint, 2013).

Such arguments have been strengthened by the formation of the European single market, which represents a substantial deepening of the European integration programme (Grin, 2003; Egan and Guimaraes, 2017). The origin of the single market is a 1985 White Paper that identified, proposed and articulated an extensive set of about 300 measures. The objective of these measures was to complete what was known at the time as the common or internal market (Young, 2015). Although the 1957 Treaty of Rome created a common market based on the free movement of goods, people, services and capital, by the early 1980 s, despite substantial progress with implementing the free movement of goods, it was perceived that significantly more integration was needed to increase the free movement of people, services as well as capital. The 1986 Single European Act changed the decision-making process in the European institutions (from unanimity to a qualified majority) and established a deadline for completing the implementation of the measures agreed upon (December 31, 1992).

Dunning (1997), Neary (2002) and Kalotay (2006), among others have considered the potential impact of the singe market on FDI, but it has rarely been spelt out. In addition to stimulating FDI by motivating production by firms from non EU members to avoid tariffs placed on exports, the single market may stimulate additional FDI from within and outside the EU. To understand this, we draw on Dunning's (1993) categorization of the motives for FDI into those that are market-seeking, efficiency-seeking, resource-seeking and strategic asset-seeking. In recent years we have seen an increase in FDI motivated by strategic asset-seeking, as multinationals, especially from emerging markets, seek to purchase brands and technologies in order to upgrade their own capabilities. Because the EU is a region of high technological competence and sophisticated brands, and is strengthened by the single market and EU innovation policies (El-Agraa, 2011), much of this FDI has come to the EU (Estrin et al., 2018). Examples include the purchase by Tata of Jaguar Landrover; by Geely of Volvo and by Arcelik of Grundig.

The single market has been a major driver of FDI since its formation. This is because it created a unified market across Europe, so market-seeking FDI from outside the EU would be strongly attracted to the EU because of the size of the domestic market and the possibilities of exploiting economies of scale and reducing transaction costs in the creation of overseas subsidiaries (Aristotelous and Fountas, 1996). As the EU is for the most part not a region of low costs or natural resource munificence, market-seeking motives are 
likely to be the predominant driver of external FDI (Kalotay, 2006). The single market is also likely to increase FDI between member states, because of the significant differences in costs among them, especially labour costs, combined with relatively short supply chains and low transaction and coordination costs. Thus, efficiency-seeking motives probably predominated in intra-EU FDI resulting from enlargement (Bevan and Estrin, 2004), with, for example, car companies relocating plants from higher to lower cost locations within the Union and just-in-time supply chains being created among Germany, the Czech Republic and Slovakia.

However, empirical work on the impact of EU membership and the role of the single market on FDI has lagged behind the theoretical discussion, largely because of problems in the availability of suitable worldwide bilateral datasets. Thus, existing research on FDI and European integration has previously covered only a few source or host economies (Sanso-Navarro, 2011), usually from among advanced economies (Aristotelous and Fountas, 1996), and they have often sought to model total FDI inflows to a country (Dunning, 1997; Neary, 2002), rather than the determinants of inter-country flows, although it is the latter that allows one to identify the impact of various forms of economic integration for group members and non-members, including the membership of the EU, the North American Free Trade Agreement (NAFTA), the European Free Trade Association (EFTA) and the Southern Common Market (Mercosur).

In contrast, the general literature on the determinants of FDI has exploited the growing availability of country-to-country (bilateral) FDI datasets to move beyond explaining single country inflows from the rest of the world. This work has been based on the use of gravity models, already employed in the analysis of trade patterns (Baier and Bergstrand, 2007), especially structural gravity models (Blonigen and Piger, 2014; Santos Silva and Tenreyro, 2006) enabling researchers to test, for example, the effects of a range of international agreements and arrangements on FDI inflows (Baier et al., 2014; Head and Mayer, 2014). Even so, the first gravity-based FDI studies used relatively simple estimation methods and covered only developed economies with quite short datasets, often only around ten to 15 years (Petroulas, 2007; Taylor, 2008) so their findings, while stimulating, were not necessarily robust.

However, bilateral data on FDI inflows have recently been made available from The United Nations Conference on Trade and Development (UNCTAD) for almost every economy in the world, while previously such bilateral data as were available were restricted to Organisation for Economic Co-operation and Development (OECD) economies (Schiavo, 2007). This enables a study of the effects of EU membership on FDI, not only for countries in the EU itself (De Sousa and Lochard, 2011), or between EU members and other advanced economies (Bevan and Estrin, 2004) but also for the first time including FDI from emerging economies. This is critical because in recent years FDI from emerging economies has represented up to a third of total outflows and China has often been the largest single FDI source economy (UNCTAD, 2019).

In this article we therefore exploit new long and global bilateral datasets, using frontier estimation methods, to provide the first robust measures of the effects of EU membership and the single market on FDI, and to compare them with the impact of other models of economic integration, including the NAFTA and Mercosur agreements. Our approach therefore follows Lawrence (1996) in distinguishing between shallow and deep integration, with the former being largely economic while the latter 
involves a significant degree of political integration as well. Thus, the EU represents the most significant, long-lasting and continuously evolving example of deep integration (König and Ohr, 2013), while NAFTA or Mercosur are examples of shallow economic integration. ${ }^{1}$ World Trade Organization (WTO) membership currently represents the lowest degree of integration for most advanced market and emerging economies. Our empirical analysis applies structural gravity models that have been used extensively in the international trade literature where bilateral data have been available for longer time (Anderson, 2011).

Our work is perhaps the first to use a huge new FDI data resource; the comprehensive UNCTAD bilateral FDI dataset. ${ }^{2}$ This allows us to consider a much wider range of countries, (142, including all the principal emerging economies), and a much longer period (1985-2018), than previous studies. Thus, we can estimate the effects of integration over a much longer time than used in previous studies, and also compare the effects of EU membership with other trading arrangements. It also facilitates the use of the most advanced econometric methods.

There are three main novel findings. We find the impact of EU membership on FDI on the host economy is always positive, significant and quite large, in the order of 60 per cent for inward investment from outside the EU, and around 50 per cent for intra-EU FDI. A second important finding is that the effect of the EU membership on FDI is significantly larger than membership of free trade area agreements, such as NAFTA, EFTA and Mercosur, supporting the view of the benefits of deep economic integration compared with shallow integration in capital inflows as well as trade. A third novel and important finding is that we are able to separate econometrically the effects of the EU membership before and after the implementation of the single market in 1993. Furthermore, when including multilateral trade resistance terms (MTRs) in the empirical model specification, we exploit more demanding methods than our baseline models, and show that the single market is the cornerstone of the differential impact of deep compared with shallow integration. Accordingly, before the implementation of the single market, we find that EU membership does not generate a significant impact on FDI. Instead, the positive significant impact of the EU membership on FDI takes place only after the single market is implemented.

The article is organised as follows. The next section 2 summarises the previous literature and sets up the framework we use for our empirical analysis. Section 3 presents the dataset providing extensive details because it has not been used before. Section 4 discusses our econometric estimates. The conclusion discusses the implications for policy and future research.

\section{FDI and Integration}

We first outline the framework used to identify and measure the effects of EU membership on FDI. As noted, the distinction between shallow and deep integration is important for our analysis: shallow integration is restricted to economic integration and epitomised

\footnotetext{
${ }^{1}$ Campos et al. (2019) argue that deepening the EU reached institutional integration when member countries delegate to supernational institutions (at least partially) political control over selected policies that go beyond those traditionally affected by trade agreements and related competition policies.

${ }^{2}$ See for details http://unctadstat.unctad.org/wds/ReportFolders/reportFolders.aspx?sCS_ChosenLang=en.
} 
by the free trade area model, while deep integration combines economic and political aspects, for example, a customs union in which economic ties are supported by the creation of common institutions to manage conflicts. This is exemplified by the EU, especially the single market (Campos et al., 2019). However, many major economies like China or Japan, while deeply involved in the global economy, have undertaken neither deep nor shallow economic integration with partners, though they may have signed some free trade agreements, especially in recent years.

The literature on the effects of EU policies and programmes on FDI is surprisingly thin. Thus, FDI has not received the same attention as the issues of trade and migration, perhaps because the EU did not have an explicit policy on cross-border investment until very recently. However, the freedom of cross-border movement of capital is one of the four pillars of the single market. By reducing restrictions on capital flows across EU member states, the single market deepens EU integration by increasing competition and specialization (Badinger, 2007) and by improving the allocation of resources and generating economies of scale and scope (Baldwin, 1989). Associated with this, the diffusion of best managerial practises and new products is also expected to foster innovation and ultimately to increase productivity.

Our empirical analysis is based on the gravity model (Anderson, 2011; Anderson and van Wincoop, 2003; Blonigen, 2005). Clear micro-foundations for the use of the gravity equation in the analysis of trade flows were provided by Anderson (1979), who derived a trade gravity equation using the properties of Cobb-Douglas expenditure function. More generally, in the late 1970s and early 1980s the emergence of a new trade theory led to a variety of theoretical foundations for a trade gravity equation (Baldwin and Taglioni, 2007). The gravity model has also been successfully applied to most other forms of bilateral cross-border flows, including migration and FDI (Baldwin and Taglioni, 2011; Head and Mayer, 2014), though as an empirical rather than a theoretical relationship. ${ }^{3}$ The fundamental idea is that the forces driving the main economic relations between countries are similar to those identified by Newton in his law of gravity, namely mass and distance. In the case of FDI, the gravity model proposes that an empirical relationship drives the flows of FDI between two economies in terms of the size (GDP) of the source (home) economy, the size of the recipient (host) economy and the distance between them. The effect of home and host GDP was expected to be approximately linear and positive while distance was expected to have a non-linear and negative effect. Distance was usually taken to reflect a range of transactional and frictional costs and is often measured geographically or by factors such as legal, institutional or cultural differences (Ghemawat, 2001). In the applications of gravity models to trade, Baier et al. (2008) calculate that membership of the EU leads to increases in bilateral international trade of the order of between 127 and 146 per cent after 10 to fifteen years. This compares favourably with equivalently estimated benefits from shallow integration; EFTA membership generates increases in bilateral trade of only about one quarter of the size.

\footnotetext{
${ }^{3}$ Thus, the gravity model started out as a purely empirical model framework but has been given solid theoretical foundations for trade flows. However, because the theory relies on market-clearing conditions for an expenditure equation (Baldwin and Taglioni, 2007) one cannot extend the model from trade, which is an output, to FDI, which is an input factor. 
The basic gravity equation model for estimating the impact of EU membership on FDI is therefore the following Poisson pseudo maximum likelihood (PPML) specification:

$$
F D I_{o, d, t}=\exp \left[\alpha_{0}+\alpha_{1} E U_{o, t}+\alpha_{2} E U_{d, t}+\alpha_{3} \ln X_{o, t}+\alpha_{4} \ln X_{d, t}+\mathrm{I}_{\mathrm{t}}+\eta_{o, d}\right]+u_{o, d, t}
$$

where $F D I_{o, d, t}$ stands for unidirectional - sender to target - FDI flow and the $\ln X_{o, t}$ is a vector of the natural logarithm of characteristics of the origin (sender, partner) country, $o$, in year $t$. Similarly, $\ln X_{d, t}$ is a vector of the natural logarithm of characteristics of the destination $d$ (target, reporter) economy, in year $t$. The characteristics vector includes the size of the economy (GDP) as well as indicators of time-varying economic distance (such as GDP per capita). Finally, $E U_{o, t}$ and $E U_{d, t}$ are the two main variables of interest, constructed in the standard way as dummy variables. ${ }^{4}$

There has been considerable methodological progress in the application of gravity models in recent years (Santos Silva and Tenreyro, 2006; Bergstrand and Egger, 2007). In particular, empirical applications have moved from the basic gravity model to the new structural gravity approach (Blonigen and Piger, 2014; Fally, 2015). This is based on the idea that moving from a cross-section design to one based on panel data allows researchers to address endogeneity bias (see also Baier and Bergstrand, 2004; Baier et al., 2008, 2014; Baier and Bergstrand, 2009; Egger and Pfaffermayr, 2004; UNCTAD, 2016). However, many of the key host and home economy variables in a gravity equation, including almost all potential indicators of distance (such as transportation costs, cultural affinity and geography), common borders, landlocked countries, ocean harbours, lack of mountains, tariffs, customs, different language/money, regulation and legal origin, are either invariant or do not change greatly over time for each pair (dyad) of countries. For these reasons, structural gravity models (Baier and Bergstrand, 2007) instead include a dyadic fixed effect $\left(?_{o, d}\right)^{5}$ specifically, a dummy variable for each pair of countries. Thus, in this formulation, distance measures - which are invariant across country pairs - are replaced by dyadic fixed effects and some country's characteristics are replaced by multilateral trade resistance terms (MTRs). The inclusion of bilateral fixed effects helps to minimize the effects of the exclusion of many of the usual suspects in explaining FDI flows. They control for country pair unobserved heterogeneity and implicitly for factors such as cultural distance and bilateral regulatory agreements. The concern over omitted variable bias is also mitigated in this way in these types of models. In our work, we also include a full set of time dummies to control for global macroeconomic shocks via year fixed effects $I_{t}$, which reflect the macro phenomena that are common across all country pairs. The $\mathrm{u}_{\mathrm{o}, \mathrm{d}, \mathrm{t}}$ is the idiosyncratic error term.

It is important to note that the coefficients of interest, $\alpha_{1}$ and $\alpha_{2}$ on the EU membership dummies, are identified via the impact of changes in economic and political relationships (and other economic variables) over time on the change in FDI flows over time. Hence the crucial importance of the length of the period used in the estimation of the model; in our case, the period is 1985-2018. Being a member of the EU will be one of the time-varying observable characteristics of a country that enter the $E U_{o, t}$ and $E U_{d, t}$ vectors of

\footnotetext{
${ }_{5}^{4}$ For a detailed description see Table A1.

${ }^{5}$ Also called symmetric or un-ordered. 
characteristics specific to a country and will include things like time-varying pair proxy for trade/investment costs and time-varying pair proxy for regulatory cultural distance.

To estimate equation (1) we utilize a Poisson pseudo-maximum likelihood (PPLM) estimation and control for dyadic fixed effects and time dummies (Santos Silva and Tenreyro, 2006). The PPML method represents the current stage in the evolution of modelling gravity equations, because there is no FDI at all between many bilateral country pairs (about 70 per cent of the pairs in our data), while FDI is very large between a few such pairs (say the UK and USA or Germany and China). The PPML estimator is designed to address the resulting highly right-skewed nature of the distribution of FDI. Standard errors are also clustered by dyadic country pair to allow for serial correlation of the errors.

\section{Data Set}

FDI reflects the objective of obtaining a lasting interest by a resident entity in one economy ('direct investor') in an entity resident in an economy other than that of the investor ('direct investment enterprise'). The lasting interest implies the existence of a long-term relationship between the direct investor and the enterprise and a significant degree of influence or control over the management of the enterprise. In general, direct investment involves both the initial transaction between the two entities and all subsequent capital and income transactions between them.

As far as measurement accounting is concerned, FDI flows record the value of cross-border transactions related to direct investment during a given period. Financial flows consist of equity transactions, the reinvestment of earnings and intercompany debt transactions, instead. Outward flows represent transactions that increase the investment that investors in the funder economy have in enterprises in a foreign economy, such as through purchases of equity or the reinvestment of earnings, less any transactions that decrease the investment that investors in the funder economy have in enterprises in a foreign economy, such as sales of equity or borrowing by the resident investor from the foreign enterprise. Inward flows represent transactions that increase the investment that foreign investors have in enterprises resident in the reporting economy less transactions that decrease the investment of foreign investors in resident enterprises. In our data we look directly at bilateral FDI flows (inflows for one country and outflow for the other) in millions of current USD.

We use the UNCTAD's bilateral FDI statistics as our primary data source. It provides data for economies reporting FDI inflows, outflows, inward stocks and outward stocks in all major countries in the world. ${ }^{6}$ In this article, we focus on FDI inward flows. ${ }^{7}$ For the purpose of international comparison, we use millions of USD as currency units. The FDI data have been merged with International Monetary Fund data $^{8}$ on the

\footnotetext{
${ }^{6}$ The data are highly correlated with the OECD bilateral FDI statistics on the overlapping countries' sample, that is, 1990 onwards. Therefore, the 1985-1989 sample has been used based on the OECD bilateral FDI source. In fact, at the end of the 1980s the number of non-OECD countries engaging in FDI was negligible, though it has increased greatly since.

${ }^{7}$ We use the whole number of 142 countries reporting FDI inflows from all around the world. The number of partners countries sending FDI - may be higher than 142, however. These are small countries that do not receive any FDI at all. Some FDI flows are negative in sign. These instances of disinvestment arise because either equity capital, reinvested earnings or intra-company loans are negative and are not offset by the remaining components. Negative flows have a real economic meaning and, because of their numerical importance, we cannot eliminate them without losing consistency, so we treat them as zero.

${ }^{8}$ International Monetary Fund DataMapper: https://www.imf.org/external/datamapper/datasets/WEO/1
} 
macroeconomic indicators of these countries including GDP and GDP per capita, both in USD purchasing power parity (PPP).

In order to build a measure of deeper economic integration, we draw from the EU website $^{9}$ and combine the information on membership of the EU and the timing of the start of the single market, both pieces of information being country and time specific. For example, the variable EU membership after the start of the single market is a binary time-variant variable equal to 1 only if the country is in the EU in a specific year and the single market has already started (after 1993). This contrasts with the variable EU prior the start of the single market, that takes the value of unity only for EU members and only up to 1992. The detailed list of variables used in this article is provided in Table A1 and summary statistics in A2 and A3. In our dataset each observation contains information of FDI flows from the source-partner to the target-reporter country, the EU membership status of both target and source countries, the macroeconomic conditions of both target and source countries, and other relevant information, such as if they are members of other plurilateral agreements (NAFTA, EFTA and Mercosur).

As far as the time span is concerned, we used all available years covered by the UNCTAD database, from 1990 to 2018, combined where relevant with the OECD dataset, which is available only for OECD countries for the period, 1985-89. The maximum possible number of observations is 174,002 . Of course, 1985 is a critical year in terms of the EU economic integration project because the Single Market Act was signed and became the institutional landmark that steered and deepened economic integration in the EU. We constructed our data as an unbalanced panel with zeros assigned due to missing values (no flows). For many country-year pairs, especially before the 1980s, bilateral FDI flows were in fact zero.

Our initial research question concerns the effect of the EU membership on target-reporting country FDI inflows, which we test via the sign and significance of a coefficient concerning whether in each year the target economy is or is not a member of the EU (EU member, target). The EU membership step-dummy captures whether the recipient of bilateral FDI flows is a member of the EU and therefore measures the overall cumulated premium through the time of the membership of increased (or decreased, if negative) FDI from any potential sender. In other words, the EU target dummy measures the premium of increased FDI towards EU members from any other country in the sample (EU and not EU). We also include a step-dummy for whether the sender-partner country in each year is a member of the EU.

\section{Empirical Analysis}

\section{The Baseline Model: PPML Estimates}

Table 1 shows estimates of our baseline model with the dependent variable being bilateral FDI flows. ${ }^{10}$ Note that because this is a structural gravity model, all the potential factors

\footnotetext{
${ }^{9}$ See https://europa.eu/european-union/about-eu/countries/member-countries_en; https://europa.eu/european-union/topics/ single-market_en.

${ }^{10}$ In the literature, FDI stock as well as flow data have been used in the estimation of gravity models because stocks tend to be more stable over time than flows. In this article, we report only results using flow data, which are more suitable for gravity estimation models. In previous work (available from the authors on request) we have estimated the same equations using stock data, with similar results.
}

(c) 2021 The Authors. JCMS: Journal of Common Market Studies published by University Association for Contemporary European Studies and John Wiley \& Sons Ltd 
Table 1: Poisson Pseudo Maximum Likelihood (PPML) Estimate of the Effect of the EU Membership on Foreign Direct Investment (FDI) Inflows: Baseline Model

\begin{tabular}{|c|c|}
\hline & FDI inflows \\
\hline EU member-reporter & $\begin{array}{c}0.47056^{* * *} \\
(0.11048)\end{array}$ \\
\hline EU member-partner & $\begin{array}{c}0.98182 * * * \\
(0.15094)\end{array}$ \\
\hline $\log \left(\mathrm{GDP}^{\mathrm{PPP}}\right)$ reporter & $\begin{array}{c}2.43140 * * * \\
(0.30628)\end{array}$ \\
\hline $\log \left(\mathrm{GDP}^{\mathrm{PPP}}\right)$ partner & $\begin{array}{c}2.41684 * * * \\
(0.30320)\end{array}$ \\
\hline Log $\left(\right.$ GDPper-capita $\left.{ }^{\mathrm{PPP}}\right)$ reporter & $\begin{array}{c}-1.72316^{* * *} \\
(0.32045)\end{array}$ \\
\hline Log (GDPper-capita $\left.{ }^{\mathrm{PPP}}\right)$ partner & $\begin{array}{c}-0.90602^{* * *} \\
(0.33233)\end{array}$ \\
\hline Constant & $\begin{array}{l}-0.14171 \\
(3.69502)\end{array}$ \\
\hline Observations & 174,002 \\
\hline Pseudo $\mathrm{R}^{2}$ & 0.7828 \\
\hline Pair FE & Yes \\
\hline Year FE & Yes \\
\hline GDP controls & Yes \\
\hline
\end{tabular}

Notes: Clustered standard errors in brackets ${ }^{* * *} P<0.01,{ }^{* *} P<0.05,{ }^{*} P<0.1$. All regressions include fixed effects for years and dyadic pair (symmetric). Reporter, country receiving the Foreign Direct Investment (FDI) inflows; partner, the country sending the FDI. PPP, purchasing power parity; FE, fixed effects.

often discussed to explain FDI, for example distance, common borders and colonial relationships, are included in the dyadic fixed effects.

The main variable of interest is the one capturing deep economic integration via EU membership, namely the estimated coefficients for the EU member target. The value is 60 per cent $\left(\mathrm{e}^{0.47}-1\right)$ and it is highly statistically significant. The gravity variables are also significant with expected signs. The economic size of the two countries is measured by GDP and the level of development is measured by GDP per capita. As we would expect from a gravity framework, the economic size of both sender and target significantly and positively affect FDI. The level of development is another indicator of distance (Ghemawat, 2001) and is therefore also often included in gravity models, especially when considering flows from countries with different levels of economic development. In line with the literature, we confirm a positive, significant and sizable effect of the EU on FDI inflows though on the basis of one of the largest and longer databases ever used on FDI. Incidentally, we also show a positive and significant effect of outward FDI (coefficient on partner) for the EU, suggesting an impact of the EU on intra-EU FDI.

How does our estimate compare with and relate to other estimates in the literature? Straathof et al. (2008) use a gravity model to examine bilateral FDI stocks. One of their specifications uses dyadic fixed effects, a somewhat different set of controls and earlier data (1981-2005). They find that EU membership yields a 28 per cent increase in its inward FDI stocks from other EU countries and a 14 per cent increase from non-EU countries (their Table 5.1, column 2). De Sousa and Lochard (2011) in related work use a short 
panel (1992-2005) to investigate whether the creation of the euro explains the increase in intra-European investment flows. They find that it increased intra-Economic and Monetary Union (EMU) FDI stocks by around 30 per cent. Petroulas (2007) finds that EMU increased inward FDI flows within the euro area by approximately 16 per cent, an estimate that is broadly confirmed by Sondermann and Vansteenkiste (2019). We can also look at the bilateral trade flows literature for a comparison. Baier et al. (2008) find that trade is increased by about 130 per cent after ten to 15 years of the EU membership, while the similar impact of EFTA membership is about 35 per cent. We find instead that EU membership increases FDI inflows by about 60 per cent and, as we show below, that is mostly driven by the single market effect.

\section{Deep Versus Shallow Integration}

We extend our baseline estimation to additional specifications and estimation methods to test in more detail the channels through which the EU might impact on FDI. Thus, we account for other economic integration agreements, elicit the role of multilateral resistance terms (MRTs) and empirically test the role of the single market, established on 1 January 1993. We report and discuss these results in the subsections below.

\section{Membership of Other Integration Agreements}

We first consider the effect of membership of other forms of economic integration, namely, NAFTA, EFTA and Mercosur, that are free trade areas (FTAs) and potentially alternatives to the WTO membership. The reason is twofold: on the one hand we conceptually compare EU membership with other integration agreements, on the other hand we test whether the use of different agreements scenarios may alter the estimated size effect of the EU membership. Our specification is as follows:

$$
\begin{gathered}
F D I_{o, d, t}=\exp \left[\alpha_{0}+\alpha_{1}^{d} E_{d, t}+\alpha_{1}^{o} E_{o, t}+\alpha_{2}{ }^{d} \text { NAFTA }_{d, t}+\alpha_{2}^{o} \text { NAFTA }_{o, t}+\alpha_{3}{ }^{d}\right. \\
\text { EFTA } \left._{d, t}+\alpha_{3}{ }^{o} \text { EFTA }_{o, t}+\alpha_{4}{ }^{d} \text { Mercosur }_{d, t}+\alpha_{4}{ }^{o} \text { Mercosur }_{o, t}+\mathrm{I}_{\mathrm{t}}+\eta_{o, d}\right]+u_{o, d, t}
\end{gathered}
$$

Because NAFTA, ${ }^{11}$ EFTA $^{12}$ and Mercosur ${ }^{13}$ are important FTAs we do control for the membership of those FTAs ${ }^{14}$ in addition to that of the EU. In equation (1), our counterfactual to EU membership is other plurilateral trade agreements, and FTAs and conformity with WTO rules. The calculated premium of the EU membership in equation (1) compares against any country outside the $\mathrm{EU}$, but within other economic integration agreements (such as FTAs) or WTO terms. In other words, from the results in Table 1 we would not be able to identify which of the two effects - FTAs versus WTO terms prevails. This is potentially problematic. In fact, the 'EU estimated premium' may be

\footnotetext{
${ }^{11}$ The NAFTA members are Canada, Mexico and the USA.

${ }^{12}$ The EFTA members are Iceland, Lichtenstein, Norway and Switzerland (with partial participation in the single market).

${ }^{13}$ Mercosur members are Argentina, Brazil, Paraguay and Uruguay. Venezuela is a full member but has been suspended since 1 December 2016.

${ }^{14}$ We exploit the most up-to-date version of the Database on Economic Integration Agreements (April 2017) from the https://sites.nd.edu/jeffrey-bergstrand/database-on-economic-integration-agreements/ website and recent updates from NAFTA, EFTA and Mercosur official websites.
} 


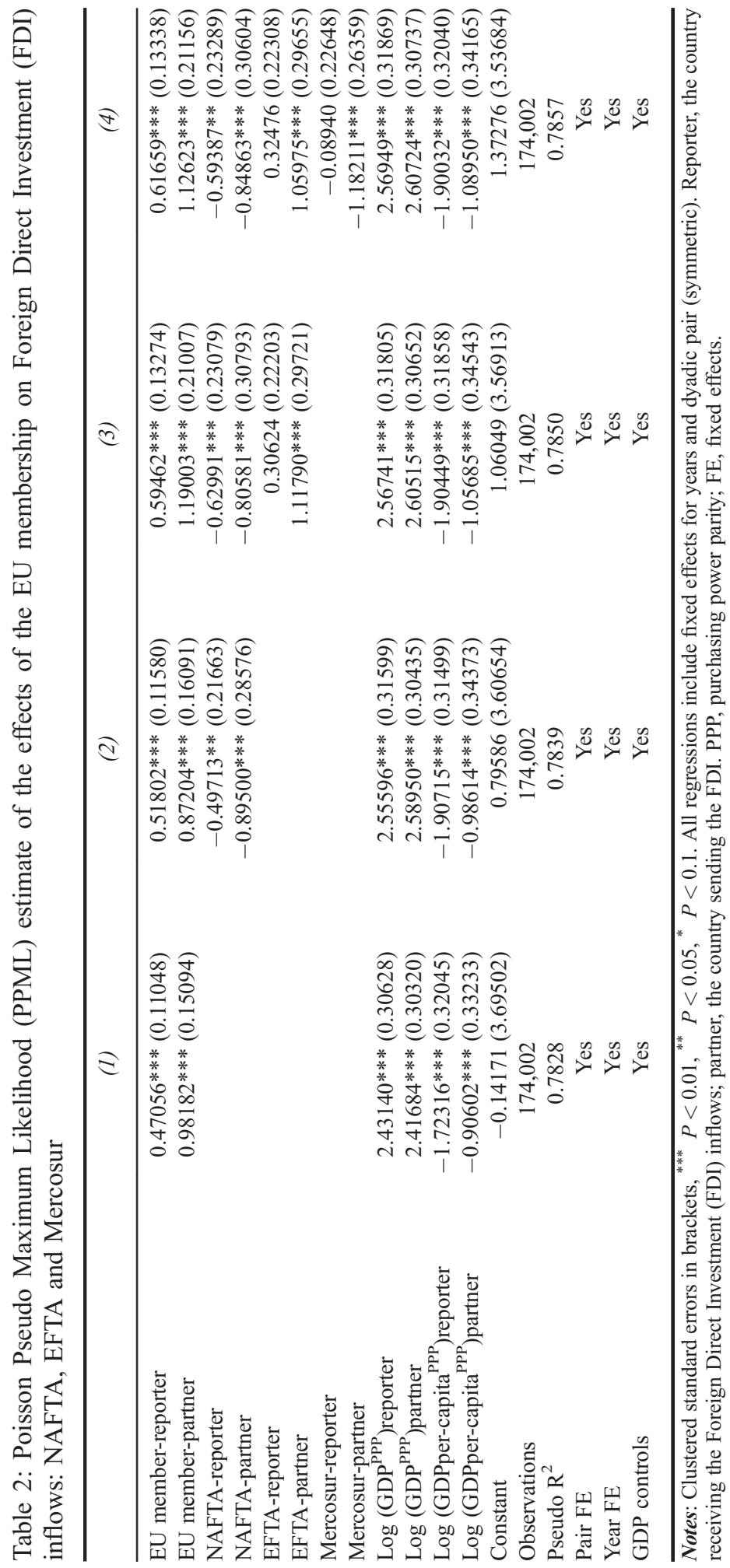

(c) 2021 The Authors. JCMS: Journal of Common Market Studies published by University Association for Contemporary European Studies and John Wiley \& Sons 
different when compared with alternative baselines: Lichtenstein and Norway (both EFTA members) or USA and Canada (both NAFTA members), or Brazil (as a member of Mercosur) or countries not in any integrated association but within bilateral FTAs as members of the WTO.

In the estimates reported in Table 2 columns 2 to 4, we add in sequence NAFTA, EFTA and Mercosur dummies, as well as repeating column 1 from Table 1 for a comparison. We find that the premium of the EU membership is now estimated to be even bigger than in the baseline scenario, the reason being that the counterfactual against which we estimate the premium is composed of countries not belonging to EU, NAFTA, EFTA or Mercosur.

The results reported in Table 2 confirm that the effect of the EU membership on FDI into targeted economies remains large, between 60 per cent $\left(\mathrm{e}^{0.47}-1\right)$ and 86 per cent $\left(\mathrm{e}^{0.62}-1\right)$. On the other hand, the coefficient on other FTAs reporter are significantly lower (or even negative) than the one on EU reporter membership dummy: the EU premium with respect to NAFTA is in the order of 230 per cent $\left(\mathrm{e}^{[0.62-(-0.59)]}-1\right)$; the EU premium with respect to EFTA has a lower bound ${ }^{15}$ in the order of 34 per cent $\left(\mathrm{e}^{[0.62-(0.32)]}-1\right)$ and finally, the EU premium with respect to Mercosur has a lower bound in the order of 100 per cent $\left(\mathrm{e}^{[0.62-(-0.08)]}-1\right)$.

We interpret this set of results to imply that $E U$ membership (deep integration) remains more effective than the other main plurilateral trade agreements (shallow integration) in delivering higher FDI from any other part of the world. The implications of these results are profound. We have tested the relationship between membership to EU and FDI over a very long time span and a comprehensively global FDI database against other forms of economic integration. The results are stark and clear. The EU remains the bloc delivering the highest premium as far FDI inflows are concerned.

\section{Time-varying Multilateral Resistance Termss}

Following UNCTAD $(2013,2016)$, we estimate a model with MTRs including time-varying sender-time and receiver-time fixed effects. MTRs absorb the size variables $\left(\ln X_{o, t}\right.$ and $\left.\ln X_{d, t}\right)$ from the structural gravity model, as well as all other observable and unobservable country-specific characteristics, which vary across these dimensions. These include various national policies, institutions, EU-reporter and EU-partner, exchange rates regimes, and so on. For this reason, we can only use a set of dummies for EU, NAFTA, EFTA and Mercosur that identify a mutual (origin and destination alike: $E U_{o, d, t} N A F T A_{o, d, t}$ EFTA $_{o, d, t}$ Mercosur $_{o, d, t}$ ) membership participation, instead. ${ }^{16}$ We use the following specification:

$$
\begin{aligned}
F D I_{o, d, t}= & \exp \left[\alpha_{0}+\alpha_{1} E_{o, d, t}+\alpha_{2} \text { NAFTA }_{o, d, t}+\alpha_{3} \text { EFTA }_{o, d, t}+\alpha_{4} \text { Mercosur }_{o, d, t}\right. \\
& \left.+\mathrm{I}_{\mathrm{ot}}+\mathrm{I}_{\mathrm{dt}}+\mathrm{I}_{\mathrm{t}}+\eta_{o, d}\right]+u_{o, d, t}
\end{aligned}
$$

In Table 3, we include both MTRs (UNCTAD, 2016) and the others three FTAs (Baier and Bergstrand, 2007). In these estimates, the impact of the EU membership remains

\footnotetext{
${ }^{15}$ The EFTA and Mercosur reporter coefficients are not significantly different from the WTO omitted category, which is why the EU premium is at least 34 per cent and 100 per cent, respectively.

${ }^{16}$ These dummies are not collinear with dyadic dummies, being time-variant. 
Table 3: Poisson Pseudo Maximum Likelihood (PPML) estimate of the effects of the EU membership on Foreign Direct Investment (FDI) inflows: Multilateral Resistance Terms and Alternative Free Trade Areas

\begin{tabular}{lcccc}
\hline & $(1)$ & $(2)$ & $(3)$ & $(4)$ \\
\hline EU-dummy & $0.40805^{* *}$ & $0.40678^{* *}$ & $0.41114^{* *}$ & $0.41114^{* *}$ \\
NAFTA-dummy & $(0.16842)$ & $(0.16893)$ & $(0.17343)$ & $(0.17343)$ \\
& & 0.06220 & 0.06117 & 0.06117 \\
EFTA-dummy & & $(0.26258)$ & $(0.26263)$ & $(0.26262)$ \\
& & & -0.05701 & -0.05701 \\
Mercosur-dummy & & & $(0.25575)$ & $(0.25575)$ \\
& & & & $-1.10137^{* *}$ \\
Observations & 134,035 & 134,035 & 134,035 & $(0.47651)$ \\
Pseudo R & & 0.7780 & 0.7780 & 134,035 \\
Partner-year FE (MTRs) & Yes & Yes & Yes & 0.7780 \\
Reporter-year FE (MTRs) & Yes & Yes & Yes & Yes \\
Pair FE & Yes & Yes & Yes & Yes \\
Year FE & Yes & Yes & Yes & Yes \\
& & & & \\
\hline
\end{tabular}

Notes: Clustered standard errors in brackets, ${ }^{* * *} P<0.01,{ }^{* *} P<0.05,{ }^{*} P<0.1$. All regressions include fixed effects for years, dyadic pair (symmetric) and country-time dummies (MTRs that stands for multilateral resistance terms). Reporter, the country receiving the Foreign Direct Investment (FDI) inflows; partner, the country sending the FDI. Regressions run on the very same sample of other tables: 39967 observation are dropped because they belong to groups with all zeros $(39,967+$ $134,035=174,002)$. FE, fixed effects.

strongly significant, 50 per cent $\left(\mathrm{e}^{0.41}-1\right)$ and (statistically) larger than any alterative shallower form of FTA. However, the interpretation is now slightly different from that of Table 1 and 2: the intra-EU FDI flow is 50 per cent higher than the inflows between countries of other economic integration areas. In particular, we elicit from column 4 that the effect is remarkably higher than any other NAFTA EFTA or Mercosur integration areas, the latter actually registering a reduced intra-FTA inflow vis-à-vis other countries.

Summing up, we estimate that the EFTA inflow premium is 37 per cent ${ }^{17}$ (Table 2) and the intra-EFTA premium to be -6 per cent (Table 3), although neither is statistically significant. Our estimates also show that the NAFTA inflow premium is -45 per cent (Table 2) while the intra-NAFTA premium is 6 per cent (Table 3), although only the former is statistically significant. Finally, we estimate the Mercosur inflow premium is -9 per cent (Table 2) while that of the intra-Mercosur premium is -67 per cent (Table 3), although only the latter is statistically significant.

\section{The single market Effect}

Finally, we consider the effects of the EU membership as well as EFTA decomposed into prior start of the single market (up to 1992) and post-single market (1993 onwards). The specification of the estimating equation in Table 4 is identical to Table 2 , and similarly Table 5 is identical to Table 3, except that we have 'decomposed the effect of the EU and

\footnotetext{
${ }^{17}$ The EFTA premium is relative lower than the EU premium, notwithstanding the participation of EFTA countries into the EEA and therefore in the single market, starting from 1994 - Norway and Iceland - and 1995 - Liechtenstein. Therefore, the whole period 1985-1994 could be considered a delayed loss of part of the premium enjoyed by countries which were already in the EU. We would like to thank an anonymous referee for this point.
} 


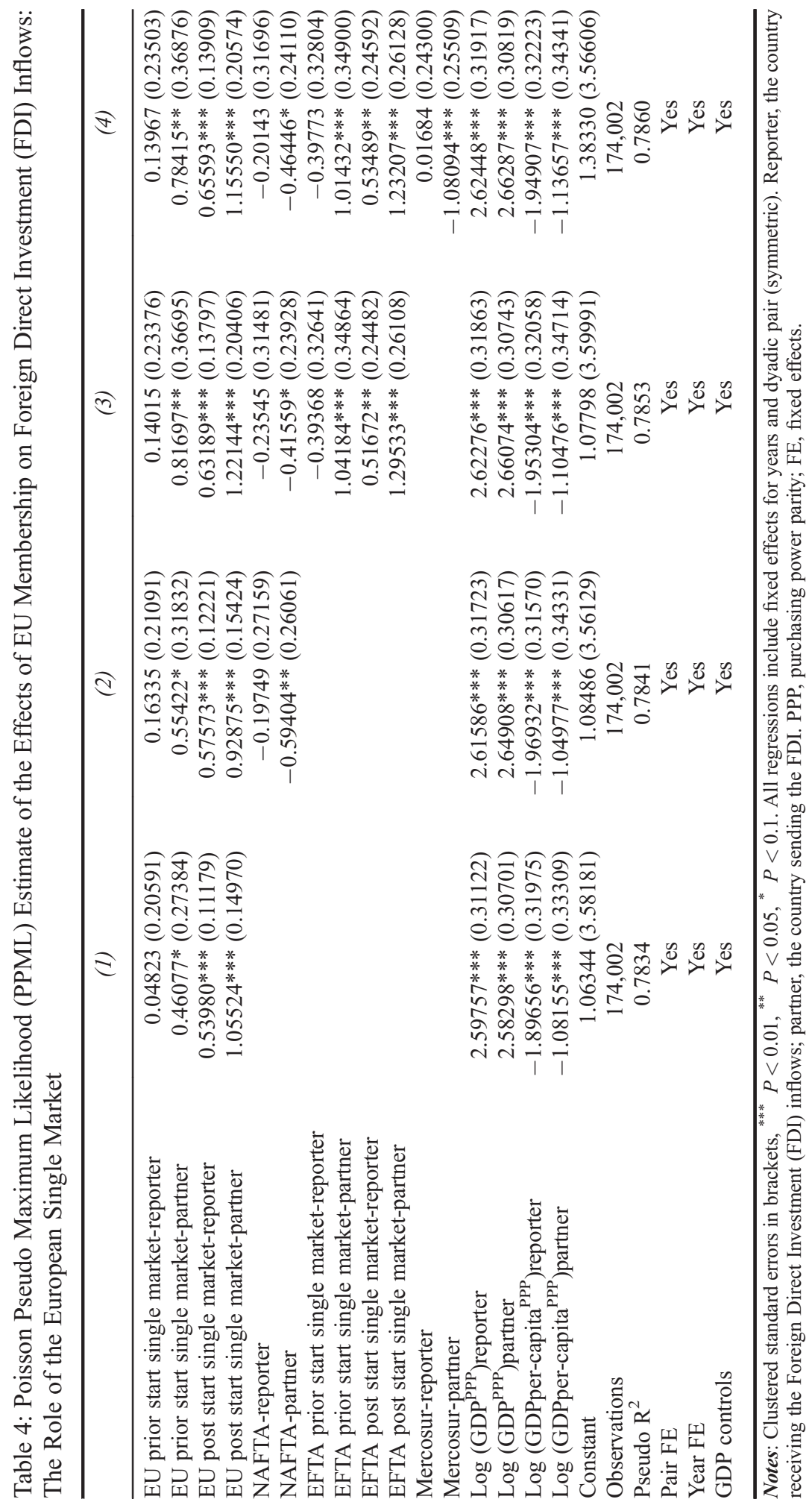




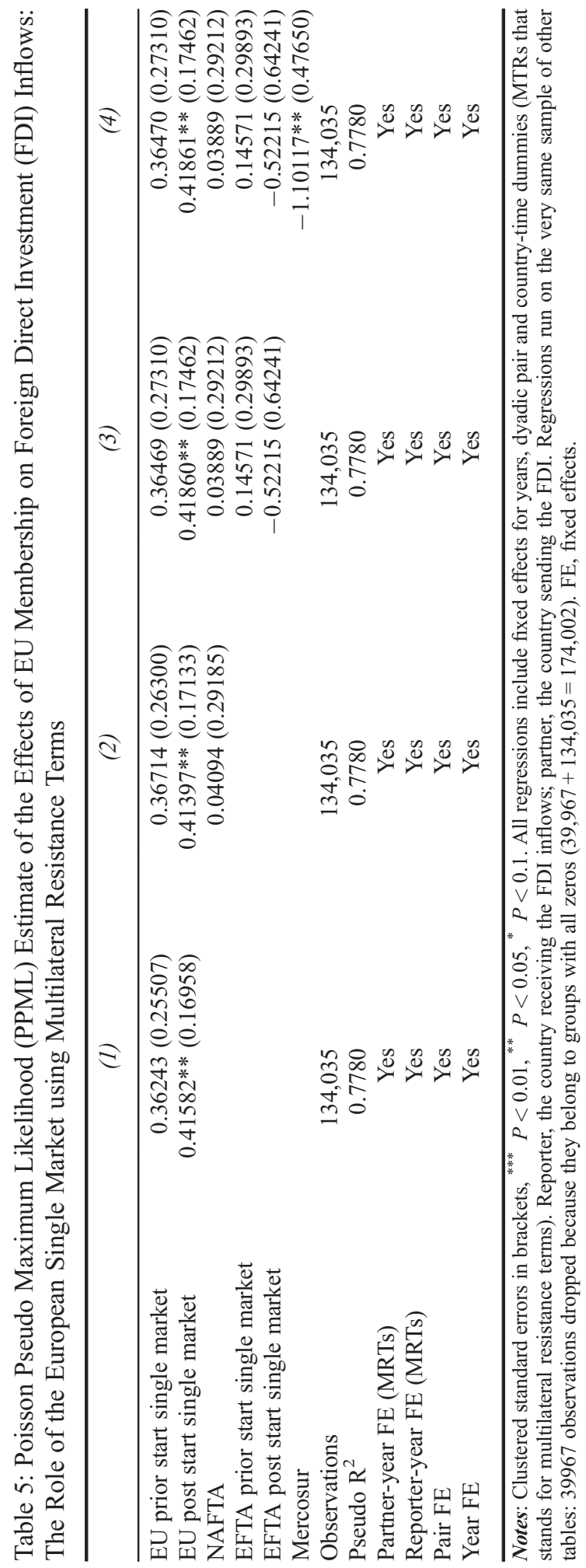

(c) 2021 The Authors. JCMS: Journal of Common Market Studies published by University Association for Contemporary European Studies and John Wiley \& Sons Ltd 
EFTA' into two periods, pre and post the establishment of the single market in January 1993. We find that pre-1993, EU and EFTA members did not experience any premium in terms of their FDI inflows. However, the establishment of the single market increased it enormously. If we look at the result of the most comprehensive regression in column 4, the EU premium is in the order of 93 per cent $\left(\mathrm{e}^{0.66}-1\right)$ for the EU and of 70 per cent $\left(\mathrm{e}^{0.53}-1\right)$ for EFTA. Incidentally, as far as outward FDI is concerned, both the EU and EFTA experienced high values even before 1993.

Finally, we test our main research question with the most stringent set of controls (MTRs, dyadic dummies and year dummies) in Table 5. Our previous results continue to hold under the exacting specification: the premium to intra-EU FDI flows is driven by the single market for EU countries. It is clear that neither EFTA nor NAFTA show benefits remotely close to those of EU combined with single market membership, whereas Mercosur membership actually suffered with respect to other agreements (as indicated by its negative coefficient).

\section{Conclusions}

How much additional FDI does a country receive because it chooses to engage in deep vis-à-vis shallower forms of economic integration? This is an important question in the European policy debate for which, surprisingly, one still finds very few answers. In this article, we calculate that EU membership increases FDI inflows by between 60 and 85 per cent (inward FDI from outside) and around 50 per cent for intra-EU. Furthermore, we show the role played by the single market to be key in that augmentation of FDI.

Because these new estimates are considerably larger than previous findings, we undertook a series of stringent tests. Firstly, we compared other levels or depths of economic integration, for example membership of EFTA, NAFTA and Mercosur as the alternative to the baseline membership to the WTO. The positive impact of EU membership on FDI is found to be much greater than that of shallower economic integration areas. Secondly, we use a fully fledged multilateral resistance terms (MTRs) estimation and find that the premium of intra-EU FDI is in the order of 50 per cent, again higher than any other integration initiative around the globe. Finally, we also test for the role of the single market, which we find to be the key driver of FDI inflows as well as of intra-EU FDI, though not for EFTA members.

The article yields various implications for future research and for policy. Regarding the implications from our results for future research, we highlight four main issues we think should be carefully investigated in the future. Firstly, there is the issue of the sectoral composition of FDI, because one suspects that the effects may be quite heterogeneous across sectors, for instance, when one considers a comparison between services and manufacturing. Although data availability remains a substantial constraint to such exercises, we believe they are and will remain of utmost importance. It is reasonable to expect that the implementation of the single market has affected capital and labour-intensive sectors differently and, indeed, that the introduction of the single currency has affected financial and non-financial sectors in dissimilar ways.

A second promising issue for future research is the possibility of a complementarity between FDI and other forms of integration (international trade and equity flows) which 
is particularly relevant in light of the increasing importance of global value chains. A third promising area of future research is to dwell deeper on various institutional aspects that have received mixed attention so far in the literature, more specifically, issues such as corruption, the rule of law, inequality and the quality of state institutions, on the one hand, and corporate tax rates and tax havens on the other.

Finally, the issue of expectations should receive a more detailed treatment. We recognise that a dummy for EU accession does not fully capture effects that occur prior to EU membership (that is, from progress in accession negotiations and/or changes to candidate status). Once a country becomes an official candidate, investors may have already formulated their expectations prior to the official membership, which may influence their investment decisions (Bevan and Estrin, 2004). Future work should try to tease out these potential differences. At the same time, our findings indicate that EU membership has a pronounced impact on FDI, in addition to the effects already identified in the literature for trade. Moreover, we do not find any evidence that these benefits can be obtained by operating under, say, WTO rules on a global basis, or by joining alternative trading areas. Our database is the first that allows for an analysis of the impact on FDI of these alternatives to the WTO.

Regarding the implications of our findings for policy, the first candid observation we must make is that we believe that FDI until very recently was one of the very few areas on which the EU was broadly silent. However, this has (in our view, correctly) changed recently. Former Commission President Juncker presented a proposal to create a first EU-wide framework for FDI during his 2017 State of the Union address. Although it was restricted to screening foreign investment into the EU, in March 2019 the proposal was adopted by the European Parliament and by the Council and has now entered into force (European Commission, 2019). Europe is still recovering from a global financial crisis in which investment has played a central role. Many well-designed policy proposals are on the table but have not received the priority (by which we mean the financial resources and political support and focus) they require. The new framework is a step in the right direction, but it does not suffice. In principle, FDI can play a key role in accelerating and deepening the recovery because of the robustness of its long-term productivity effects, which can, if properly promoted, be further supported by EU integration, and vice versa. However, this may be harder to achieve in a post-COVID world where we are already seeing some increased restrictions on FDI flows (Javorcik, 2020).

\section{Correspondence:}

Randolph Bruno

University College London

Rodolfo DeBenedetti Foundation and IZA-Bonn.

email: randolph.bruno@ucl.ac.uk

\section{References}

Alfaro, A.C., Kalemli-Ozcan, S. and Sayek, S. (2004) 'FDI and Economic Growth: The Role of Local Financial Markets'. Journal of International Economics, Vol. 64, No. 1, pp. 89-112.

Anderson, J. (1979) 'A Theoretical Foundation for the Gravity Equation'. American Economic Review, Vol. 69, No.1, pp. 106-16.

Anderson, J. (2011) 'The Gravity Model'. Annual Review of Economics, Vol. 3, pp. 133-60.

(c) 2021 The Authors. JCMS: Journal of Common Market Studies published by University Association for Contemporary European Studies and John Wiley \& Sons Ltd 
Anderson, J. and van Wincoop, E. (2003) 'Gravity with Gravitas: A Solution to the Border Puzzle'. American Economic Review, Vol. 93, No. 1, pp. 170-92.

Anderson, J. and van Wincoop, E. (2004) 'Trade Costs'. Journal of Economic Literature, Vol. 42, No. 3, pp. 691-751.

Aristotelous, K. and Fountas, S. (1996) 'An Empirical Analysis of Inward Foreign Direct Investment Flows in the EU with Emphasis on the Market Enlargement Hypothesis'. JCMS, Vol. 34, No. 4, pp. 571-83.

Badinger, H. (2007) 'Has the EU's Single Market Programme Fostered Competition? Testing for a Decrease in Mark-up Ratios in EU Industries'. Oxford Bulletin of Economics and Statistics, Vol. 69, No. 4, pp. 497-519.

Baier, S.L. and Bergstrand, J.H. (2004) 'Economic Determinants of Free Trade Agreements'. Journal of International Economics, Vol. 64, No. 1, pp. 29-63.

Baier, S.L. and Bergstrand, J.H. (2007) 'Do Free Trade Agreements Actually Increase Members' International Trade?’ Journal of International Economics, Vol. 71, No. 1, pp. 72-95.

Baier, S.L. and Bergstrand, J.H. (2009) 'Bonus vetus OLS: A Simple Method for Approximating International Trade-cost Effects Using the Gravity Equation'. Journal of International Economics, Vol. 77, No. 1, pp. 77-85.

Baier, S.L., Bergstrand, J.H., Egger, P. and McLaughlin, P. (2008) 'Do Economic Integration Agreements Actually Work? Issues in Understanding the Causes and Consequences of Growth in Regionalism'. World Economy, Vol. 31, No. 4, pp. 461-97.

Baier, S.L., Bergstrand, J.H. and Feng, M. (2014) 'Economic Integration Agreements and the Margins of International Trade'. Journal of International Economics, Vol. 93, No. 2, pp. 339-50.

Baldwin, R. (1989) 'The Growth Effects of 1992'. Economic Policy, Vol. 4, No. 9, pp. $247-81$.

Baldwin, R. and Taglioni, D. (2007) 'Trade Effects of the Euro: A Comparison of Estimators'. Journal of Economic Integration, Vol. 22, No. 4, pp. 780-818.

Baldwin, R. and Taglioni, D. (2011) 'Gravity Chains: Estimating Bilateral Trade Flows when Parts and Components Trade is Important'. NBER Working Paper No. 16672.

Baldwin, R. and Wyplosz, C. (2006) The Economics of the European Integration (Maidenhead: McGraw Hill).

Bergstrand, J.H. and Egger, P. (2007) 'A Knowledge-and-Physical-Capital Model of International Trade Flows, Foreign Direct Investment, and Multinational Enterprises'. Journal of International Economics, Vol. 73, No.2, pp. 278-308.

Bevan, A. and Estrin, S. (2004) 'The Determinants of Foreign Direct Investment into European Transition Economies'. Journal of Comparative Economics, Vol. 32, No. 4, pp. 775-87.

Blomstrom, M. and Kokko, A. (2003) 'The Economics of Foreign Direct Investment Incentives'. NBER Working Paper No. 9489.

Blonigen, B.A. (2005) 'A Review of the Empirical Literature on FDI Determinants'. Atlantic Economic Journal, Vol. 33, pp. 383-403.

Blonigen, B.A. and Piger, J. (2014) 'Determinants of Foreign Direct Investment'. Canadian Journal of Economics, Vol. 47, No. 3, pp. 775-812.

Bloom, N., Genakos, C., Sadun, R. and Van Reenen, J. (2012) 'Management Practices across Firms and Countries'. Academy of Management Perspectives, Vol. 26, No. 1, pp. 12-33.

Bruno, R.L. and Cipollina, M. (2018) 'A Meta-analysis of the Indirect Impact of Foreign Direct Investment in Old and New EU Member States: Understanding Productivity Spillovers'. World Economy, Vol. 41, No. 5, pp. 1-36.

Campos, N., Coricelli, F. and Moretti, L. (2019) 'Institutional Integration and Economic Growth in Europe'. Journal of Monetary Economics, Vol. 103, No. 1, pp. 88-104.

Crespo, N. and Fontoura, M.P. (2007) 'Integration of CEECs into EU Market: Structural Change and Convergence'. JCMS, Vol. 45, No. 3, pp. 611-632.

De Grauwe, P. (2018) Economics of Monetary Union (Oxford: Oxford University Press).

(c) 2021 The Authors. JCMS: Journal of Common Market Studies published by University Association for Contemporary European Studies and John Wiley \& Sons Ltd 
De Sousa, J. and Lochard, J. (2011) 'Does the Single Currency Affect Foreign Direct Investment?' Scandinavian Journal of Economics, Vol. 113, No. 3, pp. 553-78.

Dunning, J.H. (1993) Multinational Enterprises and the Global Economy (Harlow: Addison-Wesley).

Dunning, J. (1997) 'The European Internal Market Programme and Inbound Foreign Direct Investment'. JCMS, Vol. 35, No. 2, pp. 189-223.

Egan, M. and Guimaraes, M.H. (2017) 'The Single Market: Trade Barriers and Trade Remedies'. JCMS, Vol. 55, No. 2, pp. 294-311.

Egger, P. and Pfaffermayr, M. (2004) 'Foreign Direct Investment and European Integration in the 1990s'. World Economy, Vol. 27, No.1, pp. 99-110.

El-Agraa, A.M. (2011) The European Union: Economics and Policies (Cambridge: Cambridge University Press).

Estrin, S., Meyer, K.E. and Pelletier, A. (2018) 'Emerging Economy MNEs: How Does Home Country Munificence Matter?’ Journal of World Business, Vol. 53, No. 4, pp. 514-28.

European Commission (2019) 'Commission Staff Working Paper on Foreign Direct Investment in the EU', Brussels, SWD 108.

Fally, Thibault (2015) 'Structural Gravity and Fixed Effect'. NBER Working Paper No. 21212.

Ghemawat, P. (2001) 'Distance Still Matters'. Harvard Business Review. Available online at: https://hbr.org/2001/09/distance-still-matters-the-hard-reality-of-global-expansion. Accessed 31 October 2020.

Greenaway, D. and Kneller, R. (2007) 'Firm Heterogeneity, Exporting And Foreign Direct Investment'. Economic Journal, Vol. 117, No. 517.

Grin, G. (2003) The Battle of the Single European Market: Achievements and Economic Thought 1985-2000 (London: Kegan Paul).

Haskel, J., Pereira, S. and Slaughter, M. (2007) 'Does Inward Foreign Direct Investment Boost the Productivity of Domestic Firms?' Review of Economics and Statistics, Vol. 89, No. 3, pp. 482-96.

Head, K. and Mayer, T. (2014) 'Gravity Equations: Workhorse, Toolkit, and Cookbook'. In Gopinath, G., Helpman, E. and Rogoff, K. (eds) Handbook of International Economics Vol. 4 (North Holland: Elsevier), pp. 131-95.

Javorcik, B.S. (2004) 'Does Foreign Direct Investment Increase the Productivity of Domestic Firms? In Search of Spillovers through Backward Linkages'. American Economic Review, Vol. 94, No. 3, pp. 605-27.

Javorcik, B. (2020) Global Supply Chains Will Not Be the Same in the Post-COVID-19 world. COVID-19 and Trade Policy: Why Turning Inward Won't Work (London: CEPR Press).

Kalotay, K. (2006) 'The Impact of EU Enlargement on FDI Flows'. In Batten, J.A. and Kearney, C. (eds) Emerging European Financial Markets: Independence and Integration Post-Enlargement (Vol. 6International Finance Review) (Bingley: Emerald), pp. 473-99.

König, J. and Ohr, R. (2013) 'Different Efforts in European Economic Integration: Implications of the EU Index'. JCMS, Vol. 51, No. 6, pp. 1074-90.

Lane, P.R. and Milesi-Ferretti, G.M. (2008) 'International Investment Patterns'. The Review of Economics and Statistics, Vol. 90, No. 3, pp. 538-49.

Lawrence, R. (1996) Regionalism, Multilateralism, and Deeper Integration (Washington: Brookings Institution Press).

Mastromarco, C. and Simar, L. (2015) 'Effect of FDI and Time on Catching up: New Insights from a Conditional Nonparametric Frontier Analysis'. Journal of Applied Econometrics, Vol. 30, No. 5, pp. 826-47.

Mayes, D. (1978) 'The Effects of Economic Integration on Trade'. JCMS, Vol. 17, No. 1, pp. $1-25$. 
Medve-Bálint, G. (2013) 'The Role of the EU in Shaping FDI Flows to East Central Europe'. JCMS, Vol. 52, No. 1, pp. 35-51.

Neary, P. (2002) 'Foreign Direct Investment and the Single Market'. Manchester School, Vol. 70, No. 3, pp. 291-394.

Petroulas, P. (2007) 'The Effect of the Euro on Foreign Direct Investment'. European Economic Review, Vol. 51, No. 6, pp. 1468-91.

Sanso-Navarro, M. (2011) 'The Effects on American Foreign Direct Investment in the United Kingdom from Not Joining the Euro'. JCMS, Vol. 49, No. 2, pp. 463-83.

Santos Silva, J.M.C. and Tenreyro, S. (2006) 'The Log of Gravity'. Review of Economics and Statistics, Vol. 88, No. 4, pp. 641-58.

Schiavo, S. (2007) 'Common Currencies and FDI Flows'. Oxford Economic Papers, Vol. 59, No. 3, pp. 536-60.

Sondermann, D. and Vansteenkiste, I. (2019) 'Did the Euro Change the Nature of FDI Flows among Member States?' ECB Working Paper no. 2275.

Straathof, S, Linders, G.-J., Lejour, A and Mohlmann, J (2008) 'The Internal Market and the Dutch Economy: Implications for Trade and Economic Growth'. CPG Netherlands Document No 168.

Taylor, C. (2008) 'Foreign Direct Investment and the Euro: The First Five Years'. Cambridge Journal of Economics, Vol. 32, No. 1, pp. 1-28.

United Nations Conference on Trade and Development (UNCTAD) (2013) A Practical Guide to Trade Policy Analysis (New York: UN).

UNCTAD (2016) An Advanced Guide to Trade Policy Analysis: The Structural Gravity Model (New York: UN).

UNCTAD (2019) World Investment Report (New York: UN).

Young, A. (2015) 'The Single Market: From Stagnation to Renewal'. In Wallace, H., Pollack, M. A. and Young, A.R. (eds) Policy Making in the European Union (7th edition) (Oxford: Oxford University Press), pp. 115-40.

\section{Supporting Information}

Additional supporting information may be found online in the Supporting Information section at the end of the article.

Table A1: Variables.

Table A2: Descriptive Statistics.

Table A3: Descriptive Statistics of Zero Foreign Direct Investment inflows. 